\title{
IMPLEMENTASI KEBIJAKAN MAPALUS KAMTIBMAS DI DESA LALUMPE KECAMATAN MOTOLING KABUPATEN MINAHASA SELATAN
}

\author{
Elkana Muyu, Jeane E. Langkai, Ch. H. S. Tangkau \\ Prodi Ilmu Administrasi Negara FIS UNIMA \\ E-mail : elkanamuyu96@yahoo.com
}

\begin{abstract}
ABSTRAK
Penelitian ini bertujuan untuk mengetahui : Implementasi kebijakan dan faktor-faktor determinan implementasi kebijakan Mapalus Kamtibmas Di Desa Lalumpe Kecamatan Motoling Kabupaten Minahasa Selatan dengan menggunakan pendekatan kualitatif, dengan teknik pengumpulan data melalui observasi, wawancara dan dokumentas. Hasil penelitian menunjukkan bahwa: 1) Pemerintah desa dan Bhabinkamtibmas belum melakukan komunikasi dan sosialisasi secara intensif tentang kebijakan Mapalus Kamtibmas, 2) Belum tersedia sumberdana yang memadai untuk menunjang implementasi kebijakan Mapalus Kamtibmas, 3) Implementer belum secara sungguh-sungguh memiliki komitmen mengimplementasikan kebijakan Mapalus Kamtibmas di desa Lalumpe, 4) implementer belum memahami dengan tepat tentang kebijakan Forum Mapalus Kamtibmas. Determinan implementasi kebijakan Mapalus Kamtibmas adalah: 1) Komitmen, 2).Sumberdaya dan sumberdana, 3) komunikasi dan sosialisasi. Untuk itu disarankan sebaiknya: 1) Pemerintah desa dan Bhabinkamtibmas melakukan komunikasi dan sosialisasi secara intensif tentang kebijakan Mapalus Kamtibmas, 2) tersedia sumberdana yang memadai untuk menunjang implementasi kebijakan Mapalus Kamtibmas, 3) Implementer secara sungguh-sungguh memiliki komitmen mengimplementasikan kebijakan Mapalus Kamtibmas, 4) implementer memahami dengan tepat tentang kebijakan Forum Mapalus Kamtibmas.
\end{abstract}

\section{Kata Kunci: Implementasi, Determinan, Kebijakan Mapalus KAMTIBMAS}

\section{PENDAHULUAN}

Peraturan Gubernur Sulawesi Utara Nomor 08 Tahun 2012 Tentang Pembentukan Forum Mapalus Kamtibmas Di Provinsi Sulawesi Utara bertujuan membentuk forum untuk membina dan meningkatkan kesadaran masyarakat untuk mampu memelihara ketertiban, keamanan dan menanggulangi bencana alam serta menjaga/melindungi keselamatan jiwa, harta benda dari berbagai ancaman baik dalam maupun luar. Mapalus Kamtibmas adalah semangat gotong royong dengan menghimpun dan melibatkan aparat keamanan, Pemerintah Desa dengan masyarakat untuk saling menolong dan bekerja sama secara aktif dan mencari akar permasalahan, memecahakan masalah sosial serta mencari solusi dalam rangka mewujudkan kenyamanan, keamanan dan ketertiban masyarakat untuk terlaksananya program pembangunan pemerintahan dan kemasyarakatan yang ada di Desa. Mapalus Kamtibmas terdiri dari Pemerintah Desa, Bhabinkamtibmas, Babinsa, FKDM, LKMD, Potmas yang terdiri dari Tokoh Adat, Tokoh Masyarakat, Tokoh Agama, LSM, Professional.

Tugas pokok Mapalus Kamtibmas adalah: a) Melaksanakan TUPOKSI dan peranan masing-masing sesuai perundang-undangan; b) melaksanakan tugas secara bersama-sama membina/memberdayaan masyarakat desa, mencari dan mengumpulkan data/informasi tentang potensi bencana alam, non alam dan bencana sosial serta permasalahan di bidang IPOLEKSOSBUDHANKAM; c) Melaporkan data/informasi terkait permasalahan yang terjadi dimasyarakat; d) Memonitoring pelaksanaan 
program pembangunan yang dilaksanakan Pemerintah di Desa/Kelurahan; e) Melakukan upaya penyelesaian konflik/persoalan hukum yang terjadi di masyarakat dengan mengedepankan upaya musyawarah dan mufakat; f) Menjadi konsultan setiap persoalan yang dihadapi masyarakat.

Berdasarkan pada kebijakan tersebut maka di Desa Lalumpe Kecamatan Motoling sudah dibentuk Forum Mapalus Kamtibmas yang terdiri dari Pemerintah Desa, Bhabinkamtibmas, Babinsa, FKDM, LKMD, Potmas yang terdiri dari Tokoh Adat, Tokoh Masyarakat, Tokoh Agama, LSM, Professional yang ditugaskan untuk melaksanakan membina keamanan masyarakat. Akan tetapi, dalam kenyataannya masih terjadi perkelahian antar pemuda yang cukup tinggi, mabuk-mabukan, pencurian, premanisme, tamu wajib lapor yang terabaikan, pergaulan bebas atau perbuatan asusila, perkelahian antar kampung.

Dalam Badan Pusat Statistik "BPS" Minahasa Selatan menunjukkan bahwa jumlah kejahatan yang dilaporkan sebesar 763 kasus sedangkan menurut jenis kejahatan yang dilaporkan sebesar 1021 kasus. Data tersebut menunjukkan bahwa terdapat permasalahan sehubungan dengan implementasi kebijakan Mapalus Kamtibmas.

Data tersebut menunjukkan bahwa forum Mapalus Kamtibmas yang sudah terbentuk di Desa Lalumpe Kecamatan Motoling belum berfungsi sebagaimana tugas pokok dan fungsi yang telah ditetapkan dalam Pergub Sulut No 08 Tahun 2012 tentang Pembentukan Forum Mapalus Kamtibmas yang bertugas dan berperan melaksanakan tugas secara bersama-sama melakukan upaya penyelesaian konflik/persoalan hukum yang terjadi di masyarakat dengan mengedepankan upaya musyawarah dan mufakat serta menjadi konsultan setiap persoalan yang dihadapi masyarakat.

Berdasarkan permasalahan maka perlu dilakukan pengkajian tentang implementasi kebijakan Peraturan Gubernur Sulawesi Utara Nomor 08 Tahun 2012 tentang Pembentukan Forum Mapalus Kamtibmas khususnya menyangkut tugas dan peran melaksanakan secara bersama-sama upaya penyelesaian konflik/persoalan hukum yang terjadi di masyarakat dengan mengedepankan upaya musyawarah dan mufakat serta menjadi konsultan setiap persoalan yang dihadapi masyarakat.

Dengan mengacu pada masalah diatas, peneliti mengangkat rumusan masalah sebagai berikut : Bagaimana implementasi kebijakan dan faktor-faktor determinan implementasi kebijakan Mapalus Kamtibmas Di Desa Lalumpe Kecamatan Motoling Kabupaten Minahasa Selatan?

\section{TINJAUAN PUSTAKA \\ Konsep Kebijakan Publik}

Langkai (2015:24-25) membahas konsep publik dari Fredrickson tentang lima model formal tentang konsep publik, sebagai berikut : a) model perspektif pluralis, b) model perspektif pilihan publik, c) model perspektif legislatif, d) model perspektif penyedia layanan dan e) model perspektif kewarganegaraan. Konsep publik dari lima model tersebut dapat dimaknai bahwa memahami publik harus didekati dari beberapa model formal. Subarsono (2015:2) mengutip James E. Anderson (1979), kebijakan publik sebagai kebijakan yang ditetetapkan oleh badanbadan dan aparat pemerintah. Walaupun disadari bahwa kebijakan publik dipengaruhi oleh pejabat atau badan pemerintah dalam bidang tertentu, misalnya bidang pendidikan, politik, ekonomi, pertanian, industri, pertahanan dan sebagainya.

Konsep Laswell dan Kaplan (1970:71) mengatakan bahwa kebijakan publik adalah suatu program yang diproyeksikan dengan tujuan, nilai-nilai dan praktik-praktik tertentu. Kedua konsep Easton (1965:212) mengatakan bahwa kebijakan publik adalah akibat aktivitas pemerintah. Jadi pemerintah melakukan aktivitas dalam bentuk kebijakan publik. Ketiga konsep Fredrick mengatakan bahwa kebijakan publik adalah serangkaian tindakan yang didasarkan pada usulan seseorang atau kelompok, dimana ususlan tersebut memperhitungkan kekuatan, kelemahan, peluang serta ancaman-ancaman. Keempat konsep Dye kebijakan publik adalah segala sesuatu yang dikerjakan pemerintah yang disertai alasan mengapa sesuatu itu dikerjakan. Nugroho (2011:93-94). 
Dari beberapa pendapat diatas dapat dikatakan bahwa kebijakan publik adalah suatu pilihan yang dilakukan oleh pemerintah dalam melakukan dan tidak melakukan dengan maksud untuk mencapai tujuan dan dalam hal ini pemerintah Sulawesi Utara membuat kebijakan dalam Peraturan Gubernur Sulawesi Utara Nomor 08 Tahun 2012 tentang Pembentukan Forum Mapalus Kamtibmas.

\section{Implementasi Kebijakan Publik}

Implementasi berkenaan dengan berbagai kegiatan yang diarahkan pada realisasi program. Dalam hal ini, administrator mengatur cara untuk mengorganisir, menginterpretasikan dan menerapkan kebijakan yang telah diseleksi. Halhal yang perlu diperhatikan dalam persiapan implementasi yaitu memikirkan dan menghitung secara matang berbagai kemungkinan keberhasilan dan kegagalan, termasuk hambatan atau peluang-peluang yang ada dan kemampuan organisasi yang diserahi tugas untuk melaksanakan program.

Subarsono (2015:87) kebijakan yang telah direkomendasikan untuk dipilih oleh policy makers bukanlah jaminan bahwa kebijakan tersebut pasti berhasil dalam implementasinya. Ada banyak variabel yang mempengaruhi keberhasilan implementasi kebijakan baik yang bersifat individual maupun kelompok atau institusi. Implementasi dari suatu program melibatkan upaya-upaya policy makers mempengaruhi perilaku birokrat pelaksana agar bersedia memberikan pelayanan dan mengatur perilaku kelompok sasaran.

Langkai (2015) membahas konsep implementasi kebijakan dari Mazmanian dan Sabatier (1986:4) bahwa dalam memahami implementasi kebijakan berarti berusaha memahami apa yang terjadi sesudah sesuatu program dilaksanakan atau dirumuskan.

Santoso (2009:43) mengemukakan bahwa implementasi kebijakan adalah aktivitasaktivitas yang dilakukan untuk melaksanakan sesuatu kebijakan secara efektif. Implementasi kebijakan disini penekanannya pada mengoprasionalkan secara tepat tujuan kebijakan yang telah ditetapkan dalam bentuk tindakantindakan sementara.
Dari pengertian di atas bisa dikatakan bahwa implementasi kebijakan publik adalah tindakan-tindakan yang dilakukan oleh pemerintah atau organisasi pemerintahan untuk mencapai tujuan yang telah dibuat sebelumnya.

\section{Model-Model Implementasi Kebijakan Publik}

Subarsono (2015:99-101) membahawa model implementasi dari Van Meter dan Van Horn mengatakan bahwa ada lima variabel yang mempengaruhi kinerja implementasi yakni model keberhasilan implementasi kebijakan publik adalah: 1) Standard an sasaran kebijakan; 2) Sumber daya; 3) Komunikasi antar organisasi dan penguatan aktivitas; 4) karakteristik agen pelaksana; 5) Keadaan ekonomi, sosial dan politik disekitar kebijakan.

George Edward III menyarankan untuk memperhatikan empat isu pokok agar implementasi kebijakan menjadi efektif, yaitu, communication, resource, disposition or attitudes, and bureaucratic structures (Subarsno, 2015:90). Pertama komunikasi berkenaan dengan bagaimana kebijakan dikomunikasikan kepada organisasi dan/atau publik, ketersediaan sumber daya untuk melaksanakan kebijakan, sikap dan tanggap dari para pihak yang terlibat, dan bagaimana struktur organisasi pelaksana kebijakan.

Model Grindle ini menekankan bahwa isi kebijakan menentukan keberhasilan implementasi kebijakan. Isi kebijakan yang dimaksud mencakup hal-hal berikut: 1) kepentingan yang dipengaruhi kebijakan, 2) manfaat yang dihasilkan, 3) perubahan yang diinginkan, 4) kedudukan regulator kebijakan, 5) pelaksana kebijakan, 6) Sumberdaya yang digunakan.

\section{Efektivitas Kebijakan Publik}

Efektivitas berasal dari kata efektif yang mengandung pengertian dicapainya keberhasilan dalam mencapai tujuan yang telah ditetapkan. Efektivitas selalu terkait dengan hubungan antara hasil yang diharapkan dengan hasil yang sesungguhnya dicapai. Seperti yang dikemukakan oleh The Lyang Gie (1977:133) mengemukakan bahwa efektifitas adalah suatu keadaan yang mengandung pengertian mengenai 
terjadinya suatu atau akibat yang dikehendaki. Kalau seseorang melakukan suatu perbuatan tertentu yang memang dikehendakinya, maka orang itu dikatakan efektif kalau menimbulkan akibat dan mempunyai maksud sebagaimana yang dikehendakinya. Jadi dapat dikatakan bahwa efektifitas berhubungan dengan apa yang telah direncanakan dapat kita capai dengan sebaik-baiknya.

\section{Regulasi Terkait Implementasi Kebijakan}

Negara berkewajiban melindungi segenap bangsa Indonesia dan seluruh tumpa darah Indonesia dan untuk memajukan kesejahtraan umum, mencerdaskan kehidupan bangsa, dan ikut melaksanakan ketertiban dunia yang berdasarkan kemerdekaan, perdamaian abadi dan keadilan sosia (Alinea IV Pembukaan UUD1945). Keamanan dalam negeri merupakan bentuk perwujudan internal security dari sebuah negara terhadap rakyatanya.

Dalam Peraturan Gubernur (Pergub) No. 08 Tahun 2012 tentang Pembentukan Forum Mapalus Kamtibmas di Provinsi Sulawesi Utara, Bab I pasal 1 ayat 1 Mapalus Kamtibmas adalah semangat gotong-royong, menghimpun dan melibatkan aparat keamanan pemerintah desa/kelurahan dengan masyarakat untuk saling menolong dan bekerja sama secara aktif dalam mencari akar permasalahan, memecahkan masalah sosial serta mencari solusi dalam rangka mewujudkan kenyamanan, kemaman dan ketertiban masyarakat untuk terlaksananya program pembangunan, pemerintahan dan kemasyarakat yang ada di desa/kelurahan. Tujuan pembentukan forum ini adalah untuk memberikan pembinaan dan meningkatkan kesadaran masyarakat agar mampu dan dapat memelihara ketertiban, kemanan dan menaggulangi bencana alam serta menjaga/melindungi keselamatan jiwa, harta benda dari berbagai ancaman baik dalam maupun dari luar (Bab II pasal 2).

Dalam Bab III Pasal 5 Tugas Pokok Forum Mapalus Kamtibmas adalah : 1) melaksanakan tugas pokok, fungsi dan peranan masing-masing sesuai dengan peraturan perundang-undangan ; 2) dalam pelaksanaan Mapalus Kamtibmas unsur pelaksana melaksanankan tugas secara bersamasama melakukan pembinaan/pemberdayaan masyarakat desa, mencari dan mengumpulkan data/informasi tentang potensi bencana alam, non alam, dan bencana sosial serta permasalahan di bidang Ideologi, Politik, Ekonomi, Sosial Budaya, Pertahanan dan Keamanan; 3) melaporkan data/informasi yang di peroleh terkait permasalahan yang terjadi di masyarakat secara berjenjang kepada Satuan Atas; 4) melakukan monitoring pelaksanaan program pembangunan yang dilaksanakan oleh pemerintah di Desa/Kelurahan; 5) melakukan upaya-upaya penyelesaian konflik/persoalan hukum yang terjadi di masyarakat (restorative justice) dengan mengedepankan upaya musyawarah dan mufakat; 6) menjadi konsultan setiap persoalan yang di hadapi masyarakat.

\section{METODOLOGI PENELITIAN}

Metode yang digunakan dalam penelitian ini adalah metode penelitian kualitatif. Penelitian ini menggunakan pengumpulan data melalaui wawancara dan dokumentasi. Teknik analisis data yang digunakan akan didasarkan dengan berbagai teknik yakni, dengan wawancara, observasi, dokumentasi (triangulasi). Menurut Miles dan Huberman (1992:112) bahwa aktifitas dalam analisis data kualitatif dilakukan dengan cara interaktif dan berlangsung secara terus menerus sampai tuntas sehingga datanya jenuh. Aktivitasnya yaitu reduksi data, penyajian data dan penarikan kesimpulan. Pengujian keabsahan data,peneliti menggunakan 4 (empat) kriteria utama yang dikemukakan oleh Lincoln dan Guba (dalam Moleong 2000:173), guna menjamin keabsahan data penelitian kualitatif, yaitu: Derajat Kepercayaan (Creadibility), Derajat Keteralihan (Transferbility), Derajat Ketergantungan (Dependability) dan Derajat Kepastian (Confirmability).

\section{PEMBAHASAN HASIL PENELITIAN}

Pada penelitian implementasi kebijakan Mapalus Kamtibmas Di Desa Lalumpe Kecamatan Motoling Kabupaten Minahasa Selatan peneliti menggunakan metode penelitian kualitatif. Dengan menggunakan teknik pengumpulan data observasi, wawancara dan dokumentasi. Implementasi berkenaan dengan berbagai kegiatan yang diarahkan pada realisasi program. 
Dengan demikaian data yang ditemukan bahwa Pemerintah Desa dan Bhabinkamtibmas kurang melakukan komunikasi atau sosialisasi kepada masyarakatat mengenai kebijakan Mapalus Kamtibmas dan belum tersedianya sumberdana untuk menunjang keberhasilan kebijakan Mapalus Kamtibmas serta keterbatasan fasilitas membuat unsur pelaksana tidak terlibat aktiv dalam penyelesaian masalah. Dalam pelaksanaan kebijakan Pergub Sulut No 08 Tahun 2012 Tentang Mapalus Kamtibmas terdapat kekurangan yakni sikap pelaksana kebijakan kurang berkomitmen dalam tugas dan tanggung jawab serta masih kurangnya keterlibatan unsur pelaksana, sehingga pelaksanaan kebijakan Mapalus Kamtibmas di desa Lalumpe belum berjalan dengan baik dan dalam kebijakan Mapalus Kamtibmas masih ada kekurangan yakni implementor atau pelaksana kebijakan belum memahami dengan jelas mengenai kebijakan yang diatur oleh Pergub Sulut No 08 Tahun 2012 Tentang Mapalus Kamtibmas.

Pergub Sulut No 08 Tahun 2012 tentang Mapalus Kamtibmas merupakan satu produk kebijakan untuk diimplementasikan agar semua desa yang ada di Sulawesi Utara boleh merasakan rasa aman dan nyaman. Implementasi kebijakan tersebut sangat bermanfaat bagi masyarakat dan pemerintah desa agar bisa bekerja sama secara aktif dan mencari akar permasalahan, memecahakan masalah sosial serta mencari solusi dalam rangka mewujudkan kenyamanan, keamanan dan ketertiban masyarakat untuk terlaksananya program pembangunan pemerintahan dan kemasyarakatan yang ada di Desa.

Pertama, Edward III meyarankan bahwa agar implementasi kebijakan menjadi efektif, maka empat isu pokok harus diperhatikan yaitu 1) komunikasi, 2) sumber daya, 3) disposisi, 4) dan struktur birokrasi. Komunikasi berkenaan dengan bagaimana kebijakan dikomunikasikan kepada organisasi pelaksana atau implementer atau publik. ketersediaan sumberdaya manusia maupun sumberdana untuk melaksanakan kebijakan, disposisi yang berhubungan dengan sikap dan komitmen yang kuat dari pemerintah dan implementer untuk mencapai keberhasilan kebijakan, struktur birokrasi yang berkenaan dengan pelaksana kebijakan.

Hasil penelitian bahwa pemerintah desa, babinsa dan bhabinkamtibmas kurang melakukan komunikasi atau sosialisasi kepada masyarakat mengenai kebijakan Mapalus Kamtibmas, melainkan hanya sebatas himbauan atau pengumuman lewat pengerah suara dan acara-acara kemasyarakatan. Informasi tersebut dibenarkan oleh Hukum Tua desa Lalumpe bahwa sosialisasi kurang dilakukan kepada masyarakat karena mereka kurang memiliki dana untuk melakukan sosialisasi atau komunikasi.

Kondisi sosialisasi komunikasi kebijakan Mapalus Kamtibmas di Desa Lalumpe Kecamatan Motoling sejalan dengan apa yang dikemukakan oleh Van Meter dan Van Horn yang menegaskan bahwa keberhasilan implementasi kebijakan publik ditentukan oleh kegiatan implementasi dan komunikasi antar organisasi yang terlibat dalam kebijakan publik, Subarsono (2015:99-101).

Kedua, yang harus dilakukan implementasi Mapalus Kamtibmas adalah meneganai sumber daya manusia dan sumberdana oprasional kegiatan. Van Meter dan Van Horn mengatakan implementasi kebijakan perlu dukungan sumberdaya manusia maupun sumberdaya nonmanusia. Dimana manusia harus mempunyai pengelolaan maka implementor harus dilatih. Sedangkan sumberdaya non-manusia seperti sumber dana dalam menopang oprasional kegiatan. Karena sumber dana sebagai sumber pembiayaan implementasi kebijakan yang berpengaruh bagi kelancaran implementasi lebijakan.

Hasil penelitian bahwa pos kamling di tiap jaga sampai saat ini belum terealisasi hanya di programkan dan tidak ada peralatan khusus yang diberikan pemerintah untuk mengamankan ketika terjadi perkelahian serta untuk menunjang keberhasilan kebijakan Mapalus Kamtibmas. Informasi tersebut dibenarkan oleh Hukum Tua desa Lalumpe bahwa kondisi sumberdana yang belum ada untuk menunjang keberhasilan kebijakan Mapalus Kamtibmas.

Kondisi sumberdana Mapalus Kamtibmas di desa Lalumpe kecamatan Motoling sejalan dengan apa yang dikemukakan oleh Edward III yang menegaskan bahwa 
sumber daya adalah faktor penunjang walaupun isi kebijakan ini sudah dikomunikasikan secara jelas dan konsisten, tetapi apabila implementor kekurangan sumber daya untuk melaksanakan, implementasi tidak akan berjalan efektif. Sumber daya tersebut dapat berwujud sumber daya manusia, yakni kompetisi implementor, dan sumber daya finansial, Subarsono (2005:90-92).

Ketiga, implementasi kebijakan yang dibuat oleh pemerintah Sulawesi Utara mengenai kebijakan Mapalus Kamtibmas tentunya membutuhkan pelakasana yang mempunyai komitmen atau kesungguhan hati dalam melaksanakan peraturan pemerintah untuk mencapai tujuan yang telah ditetapkan sebelumnya.

Van Metter dan Van Horn menjelaskan salah satu faktor yang mempengaruhi implementasi kebijakan yakni komitmen dan dispoisisi menjelaskan bahwa implementor kebijakan sebaiknya memiliki disposisi dan komitmen yang kuat untuk berusaha mengimplementasikan kebijakan sesuai tujuannya. Tanpa disposisi dan komitmen yang kuat terhadap tujuan kebijakan, maka keberadaan implementor tersebut justru akan menghambat keberhasilan pencapaian tujuan kebijakan. Subarsono (2015:99-101).

Hasil penelitian bahwa dalam pelaksanaan kebijakan Pergub Sulut No 08 Tahun 2012 tentang Mapalus Kamtibmas masih ada kekurangan yakni sikap pelaksana kebijakan kurang berkomitmen dalam tanggung jawab serta masih kurangnya keterlibatan dari unsur pelaksana yang terkait, sehingga pelaksanaan kebijakan Mapalus Kamtibmas di desa Lalumpe yang dibuat oleh Pemerintah Sulawesi Utara belum berjalan dengan baik.

Kondisi ini sejalan dengan apa yang dikemukakan oleh Edward III dalam Subarsono (2015:90-92) menjelaskan tentang disposisi adalah watak dan karakteristik yang dimiliki oleh impolementor yakni pelaksana kebijakan baik yang ada di pemerintah desa, seperti komitmen, kejujuran dan apabila implementor memiliki disposisi yang baik seperti apa yang diinginkan oleh pembuat kebijakan maka implementasi kebijakan yang dibuat dapat berjalan dengan baik.
Keempat, implementasi kebijakan di Sulawesi Utara sangat ditentukan oleh isi kebijakan yang terdapat dalam Pergub Sulut No 08 Tahun 2012 tentang Mapalus Kamtibmas.

Edward III menjelaskan salah satu yang mempengaruhi implementasi kebijakan yaitu struktur birokrasi dimana struktur birokrasi yang dimaksud mengetahui dengan jelas isi dari kebijakan yang dibuat yakni struktur organisasi yang bertugas mengimplementasikan kebijakan memiliki pengaruh yang signifikan terhadap implementasi kebijakan salah satu aspek yang penting yaitu kebijakan yang harus jelas siapa implementornya, Subarsono (2015:90-92).

Hasil penelitian bahwa dalam Pergub Sulut No 08 Tahun 2012 tentang Mapalus Kamtibmas masih ada kekurangan yakni implementer di desa Lalumpe atau pelaksana kebijakan belum memahami dengan jelas mengenai kebijakan yang di atur oleh Pergub Sulut No 08 Tahun 2012 tentang Mapalus Kamtibmas selain itu sosialisasi mengenai Kebijakan Mapalus Kamtibmas yang masih kurang kepada masyarakat yang ada di desa Lalumpe Kecamatan Motoling.

Kondisi standar kebijakan yang ada di desa Lalumpe sejalan dengan apa yang di kemukakan oleh Van Meter dan Van Horn yang menjelaskan bahwa standard dan sasaran kebijakan harus jelas dan terukur sehingga dapat diimplementasikan dengan baik apabila standard dan sasaran kebijakan masih kurang jelas maka dapat menghambat implementasi dan mudah menimbulkan konflik diantara pelaksana kebijakan, Subarsono (2015:99-101).

\section{KESIMPULAN DAN SARAN Kesimpulan}

1. Belum tercipta komunikasi antara Hukum Tua, Perangkat Desa, Babinsa dan Bhabinkamtibmas untuk mengimplementasikan kebijakan Mapalus Kamtibmas.

2. Belum tersedia sumberdana untuk menunjang implementasi kebijakan Mapalus Kamtibmas.

3. Belum terdapat komitmen pemerintah sebagai perumus kebijakan Mapalus Kamtibmas.

4. Implementer di desa Lalumpe belum memahami kebijakan Mapalus Kamtibmas. 
5. Determinan implementasi kebijakan mapalus kamtibmas di desa Lalumpe yaitu komitmen, sumberdaya atau sumberdana, komunikasi/soialisasi dan standar kebijakan.

\section{Saran}

Berdasarkan kesimpulan diatas maka di sarankan bahwa dalam kebijakan mapalus kamtibmas sebaiknya :

1. Tercipta komunikasi antara Hukum Tua, Perangkat Desa, Babinsa dan
Bhabinkamtibmas untuk mengimplementasikan kebijakan Mapalus Kamtibmas.

2. Tersedia sumber dana untuk menunjang implementasi kebijakan Mapalus Kamtibmas.

3. Terdapat komitmen pemerintah sebagai perumus kebijakan Mapalus Kamtibmas.

4. Implementer memahami dengan jelas tujuan dan sasaran kebijakan Mapalus Kamtibmas.

\section{DAFTAR PUSTAKA}

Agus P. Erwan dan Dyah Ratih S. 2012. Implementasi Kebijakan Publik. Gadjah Mada University Press: Yogyakarta.

Akib, 2012. Kebijakan publik, Materi Kuliah, Universitas Negeri Makasar

Dunn N, William. 2000. Pengantar Analisis Kebijakan Publik. Gadjah Mada University Press: Yogyakarta.

Keban T. Yeremias. 2014. Enam Dimensi Strategis Administrasi Publik. Gava Media : Yokyakarta.

Moleong J. L. 2002. Metode Penelitian Kualitatif. PT. Remaja Rosda Karya Bandung.

Mulyadi, Deddy. 2016. Studi Kebijakan Publik dan Pelayanan Publik. Alfabeta, CV: Bandung.

Nugroho Riant. 2006. Kebijakan Publik: Untuk Negara-Negara Berkembang. Jakarta: Elex Media

Komputindo Kelompok Gramedia.

Pasolong, Harbani. 2011. Teori Administrasi Publik. Alfabeta, CV: Bandung.

Panji Santosa. 2009. Administrasi Publik Teori dan Aplikasi Good Governance. Refika Aditama Bandung.

Sugiyono, 2009. Metode Penelitian Kuantitatif Kualitatif dan R\&D. Alvabeta, CV: Bandung.

Subarsono. 2015. Analisis Kebijakan Publik Konsep Teori dan Aplikasi. Pustaka Pelajar. Yokyakarta.

Tangkau, Charles. 2012. Modul Metodologi Penelitian, UNIMA, Tondano.

Thoha, Miftah. 2008. Ilmu Administrasi Publik Kontemporer. Kencana Preda Media Grup. Jakarta.

Wahab Solichin Abdul. 2010. Analisis Kebijakan : Dari Formulasi Ke Implementasi Kebijakan Negara. Jakarta: Bumi Aksara.

Winarno, Budi.2002. Teori dan Proses Kebijakan Publik. Media Pressindo. Yogyakarta.

\section{Sumber Internet}

Arifin Ayyun. 2015. Implementasi Tugas dan Fungsi Satuan Perlindungan Masyarakat (Satlinmas) di Desa Tani Harapan Kecamatan Lao Janan KAbupaten Kuta Kartanegara. Fisip_Universitas Mulawarman. http://ejournal.ip.fisipunmul.ac.id/site/?p=1291 (Diakses Pada 18 Oktober 2017)

Langkai E. Jeane. 2015. Dampak Implementasi Kebijakan Pembangunan Berbasis Lingkungan Terhadap Kesejahtraan Masyarakat $\quad$ Di $\quad$ Kota Manado. http://mcser.org/journal/index.php/mjss/article/view/8896 (Di Akses Pada 21 April 2018)

Wawointana Thelma. 2016. Pengembangan Kelembagaan Di Sektor Publik (Studi Kasus Peran "Mapalus" dalam Menciptakan Keamanan Dan Ketertiban Masyarakat Di Kabupaten Minahasa Provinsi Sulawesi Utara). http://scholar.google.co.id/citations?user=480.com (Diakses Pada 21 April 2018)

https://kebijakanpublikindonesia.wordpress.com. Diakses Pada 18 Oktober 2017, Pukul 08.15) https://id.wikipedia.org/wiki/Kebijakanpublik.com (Diakses Pada 18 Oktober 2017, Pukul 08.30) 


\section{Dokumen}

Undang-Undang Nomor 02 Tahun 2007 Tentang Kepolisian

Peraturan Kepala Kepolisian Negara RI Nomor 23 Tahun 2007 Tentang Siskamling

Peraturan Gubernur Sulawesi Utara Nomor 08 Tahun 2012 Tentang Pembentukan Forum Mapalus Kamtibmas

BPS Minahasa Selatan. 2016. Minsel Dalam Angka 2016. Minsel: Badan Pusat Statistik Kabupaten Minahasa Selatan. 